\title{
Invasive airway "Intubation" in COVID-19 patients :statistics, causes and recommendations
}

\author{
Mostafa Mohammadi \\ Associated professor, Department of Anesthesiology and Critical Care, Department of Spiritual \\ Health, Imam Khomeini Hospital Complex, Tehran University of Medical Sciences \\ E-mail: $\underline{\text { mohammadi_mm@tums.ac.ir }}$
}

Alireza Khafaee Pour Khamseh

Medical student, Islamic Azad University Tehran Medical Sciences

E-mail: A.khafaee.pour.khamseh.md@gmail.com

Hesam Aldin Varpaei*

Bachelor of science in Nursing, Tehran University of Tehran Medical Sciences

E-mail: akademik.hv@gmail.com

*corespounding author

\section{Abstract}

Background: Severe COVID-19 disease could induce acute respiratory distress which is characterized by tachypnea, hypoxia, and dyspnea. Intubation and mechanical ventilation are a strategic treatment of COVID-19 distress or hypoxia.

Methods: We searched PubMed, Embase, and Scopus databases through April 1, 2021, to identify relevant randomized control trials, observational studies, and case series.

Results: 24 studies were included in this review. Studies were conducted in the USA, China, Spain, South Korea, Italy, Iran, and Brazil. Most patients were intubated in the intensive care unit. Rapid sequence induction was mostly used for intubation. ROX index might be utilized for the predictor of the necessity of intubation in COVID-19 patients. According to the previous studies the rate of intubation reported 5 to $88 \%$. It was revealed that $1.4-44.5 \%$ of patients might be extubated. Yet obesity and age (elderly) are the only risk factors of delayed or difficult extubation.

Discussion and conclusion: Acute respiratory distress in COVID-19 patients could require endotracheal intubation and mechanical ventilation. Severe respiratory distress, loss of consciousness, and hypoxia were the most important reasons for intubation. Also, increased levels of ferritin, d-dimer, and lipase in common with hypoxia are correlated with intubation and ICU admission Mortality following intubation is reported to be 15 to $36 \%$. Awake-prone positioning in comparison to high-flow nasal oxygen therapy did not reduce the risk of intubation and mechanical ventilation. There was no association between intubation timing and mortality of infected patients. noninvasive ventilation may have survival benefits.

Keywords: Intubation, COVID-19, critical care, respiratory disease, infectious disease, hypoxia, airway management. 
medRxiv preprint doi: https://doi.org/10.1101/2021.04.08.21254439; this version posted April 11, 2021. The copyright holder for this preprint

(which was not certified by peer review) is the author/funder, who has granted medRxiv a license to display the preprint in perpetuity.

It is made available under a CC-BY-NC-ND 4.0 International license.

\section{Background}

Tracheal intubation is a clinical procedure to place a flexible tube into the trachea with the aim of keeping a safe airway and establish ventilation. Some circumstances might require intubation such as loss of consciousness, major surgeries, decreased oxygen saturation (hypoxemia), airway obstruction (laryngospasm), or respiratory disease such as acute respiratory distress syndrome [1,2]. Since this is an invasive and uncomfortable procedure, intubation is often performed under general anesthesia and a neuromuscular-blocking medication.

During the COVID-19 pandemic, as infected patients develop acute respiratory distress and respiratory failure, putting invasive airways might prevent disease progress [1,2,3]. Approximately $14-30 \%$ of hospitalized patients diagnosed with COVID-19 develop a severe respiratory failure requiring intensive care $[4,5,6]$ so that roughly $3.2 \%$ of patients with COVID-19 required intubation and invasive ventilation at some point in the disease periods [7]. The need for intubation and mechanical ventilation in those who are critically ill is vary ranging from 30 to 100 percent [8].

Currently, different statistics are provided on the intubation rate of COVID-19 patients in intensive care units. There are various statistics on the intubation of patients with COVID-19. On March 4, 2020, 3.2\% of infected cases in China required intubation [7]. Also, in a study conducted in New York, 12.2 to $33.1 \%$ of covid-19 patients needed intubation [4,9]. The duration of intubation is different for each patient. Wali et al examined the course of 5 COVID-19 patients who needed invasive oxygen therapy [10]. It was found that most patients were intubated in the first 2 days of admission. The duration of ventilation with an endotracheal tube was between 4 to 30 days. Intubation can be due to various reasons, like decreased oxygen saturation, respiratory distress, and Acute Respiratory Distress Syndrome [11]. In this situation, intubation at the right time is very important, and delayed intubation might cause patients' death [12]. Xiao Lu's studies show that mortality in intubated patients with COVID-19 is higher than in patients who did not intubate [13]. Most intubations are performed in the ICU. According to recent studies, more than $10 \%$ of COVID-19 patients in northern Italy who suffer from hypoxia were intubated in the ICU [14]. However, a unique syndrome of hypoxic COVID-19 patients has been described (labeled "the happy hypoxic") who are mentally alert and lack of significant respiratory distress despite hypoxia that would usually prompt treatment, sometimes with profoundly low oxygen saturation [15].

The timing of intubation as well as the decision to endotracheal intubation may be unique to COVID19 patients' case by case [16]. The threshold for intubation may be lower in COVID-19 since the use of high-flow nasal oxygen [2] or non-invasive ventilation may potentially increase the risk of transmission to healthcare workers. Disease transmission risk of viral respiratory infections during intubation is high, and therefore early, controlled intubation may also increase the safety margin of intubation and by allowing adequate preparation time for this high-risk procedure. The application of airborne precautions 
medRxiv preprint doi: https://doi.org/10.1101/2021.04.08.21254439; this version posted April 11, 2021. The copyright holder for this preprint

(which was not certified by peer review) is the author/funder, who has granted medRxiv a license to display the preprint in perpetuity.

It is made available under a CC-BY-NC-ND 4.0 International license .

is highly recommended throughout $[17,18]$. The most important clinical manifestations of respiratory failure in patients with COVID-19 are hypoxemia and increased work of breathing. Attention should be paid to the different effects of different oxygen therapy concentrations to avoid prolonged highconcentration oxygen therapy [19]. Due to the involvement of the alveoli in COVID-19 pneumonia, it is vital to deliver oxygen at the right concentration to maintain oxygen saturation and avoid decreased partial pressure of oxygen.

\section{Methods and Materials}

The literature search using the following search strategy was conducted on the PubMed, Embase, and Scopus databases on April 1st, 2020 to identify eligible articles: (intubation statistics and COVID- 19). The publication time was limited to 2020 onward. A total of 4,680 papers were identified by the initial search. Three reviewers independently reviewed the abstracts and full-texts. Inclusion criteria: the studies in which, among the study population, a percentage of COVID-19 infected patients (not all patients) required endotracheal intubation. Reports regarding intubation in COVID-19 which consists of the patient's intubation rate were included in this review. The main question of this review is how many patients infected by COVID-19 were intubated? and what are associated factors? 
medRxiv preprint doi: https://doi.org/10.1101/2021.04.08.21254439; this version posted April 11, 2021. The copyright holder for this preprint (which was not certified by peer review) is the author/funder, who has granted medRxiv a license to display the preprint in perpetuity.

It is made available under a CC-BY-NC-ND 4.0 International license.

This study was approved by the internal ethical committee of critical care, Imam Khomeini hospital
complex.
Ethics
code
number
IR.TUMS.VCR.REC.1399.389.

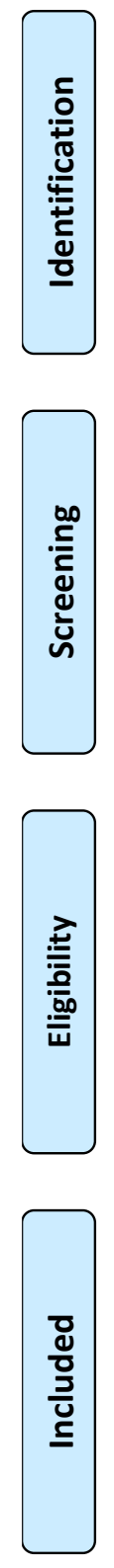

\section{Records identified through database searching} $(n=4680)$
Additional records identified through other sources

(n=0)

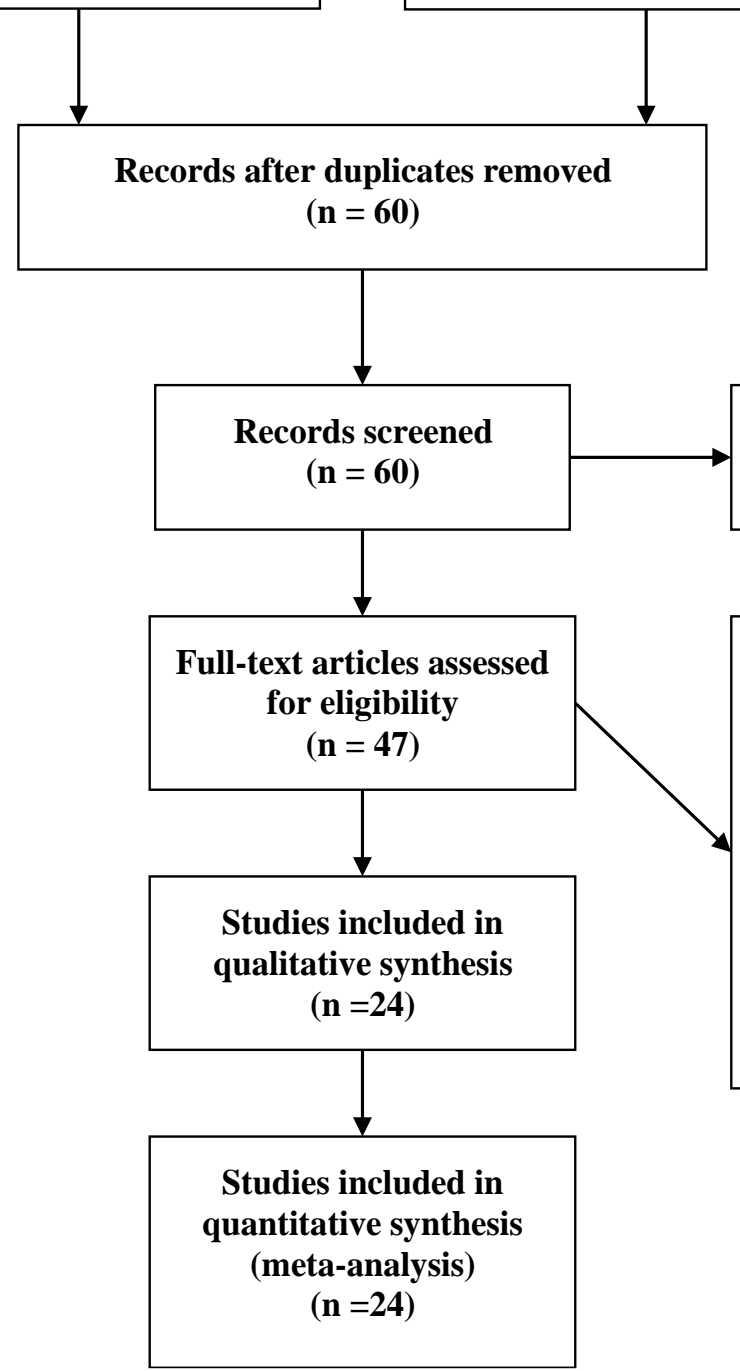

Records excluded $(\mathbf{n}=\mathbf{1 3})$

Figure 1 - PRISMA 2009 Flow Diagram

\section{Results}

Overall, 24 studies regarding the intubation rate in COVID-19 patients were included in the final analysis. Most of the patients were intubated in the intensive care unit. Studies were conducted in the USA, Spain, Italy, China, South Korea, Brazil, and Iran. 


\begin{tabular}{|c|c|c|c|c|c|c|}
\hline \multicolumn{7}{|c|}{ Table 1 - Statistics of COVID-19 patients Intubation } \\
\hline Sex & Age & Ward & Extubation Rate \% & Intubation Rate $\%$ & $\begin{array}{l}\text { Cause(s) of } \\
\text { intubation }\end{array}$ & Country \\
\hline $\begin{array}{l}210 \text { Male } \\
128 \text { Female }\end{array}$ & $\begin{array}{c}39 \\
(\text { IQR 31- 45) }\end{array}$ & $\mathrm{ED}^{1}$ & - & $\begin{array}{c}8 \% \\
28 \text { out of } 338\end{array}$ & $\begin{array}{l}\text { Respiratory } \\
\text { failure }\end{array}$ & $\begin{array}{c}\text { USA, } \\
\text { New York } \\
{[20]}\end{array}$ \\
\hline $\begin{array}{c}78 \\
\text { (Not specified) }\end{array}$ & $58.4 \pm 13.7$ & ICU & - & $\begin{array}{c}12.82 \% \\
10 \text { out of } 78\end{array}$ & $\begin{array}{l}\text { Respiratory } \\
\text { failure }\end{array}$ & $\begin{array}{c}\text { Tabriz, Iran } \\
{[21]}\end{array}$ \\
\hline $\begin{array}{c}60 \% \text { Male } \\
40 \% \text { Female }\end{array}$ & 59 & ED & - & $13 \%$ & $\begin{array}{l}\text { Long term } \\
\text { Hypoxia }\end{array}$ & USA [22] \\
\hline Mostly Male & $50-81$ & Oncology & - & $5 \%$ & $\begin{array}{l}\text { Hypoxia and } \\
\text { Lung injury } \\
\text { caused by } \\
\text { Oxygen } \\
\text { decreased }\end{array}$ & USA [23] \\
\hline Mostly Male & $47-70$ & $\begin{array}{l}\text { Infectious } \\
\text { ward }\end{array}$ & - & $26.7 \%$ & Hypoxia & USA [24] \\
\hline $\begin{array}{c}52 \%(53 / 102) \\
\text { Male } \\
48 \%(49 / 102) \\
\text { Female }\end{array}$ & $\begin{array}{c}68 \\
(\text { IQR 61-75) }\end{array}$ & ICU & - & $\begin{array}{l}57 \% \text { women } \\
59 \text { out of } 102\end{array}$ & $\begin{array}{l}\text { Hypoxic } \\
\text { respiratory } \\
\text { failure }\end{array}$ & $\begin{array}{c}\text { USA, New } \\
\text { York [25] }\end{array}$ \\
\hline
\end{tabular}




\begin{tabular}{|c|c|c|c|c|c|c|}
\hline $\begin{array}{c}78 \%(83 / 108) \text { Male } \\
22 \%(25 / 183) \\
\text { Female }\end{array}$ & $\begin{array}{c}64 \\
(I Q R \text { 57-70) }\end{array}$ & ICU & $12 / 822(1.4 \%)$ & $\begin{array}{c}20 \% \\
163 \text { out of } 822\end{array}$ & - & $\begin{array}{c}\text { Italy, Bologna } \\
{[26]}\end{array}$ \\
\hline 137(71\%) Male & $60 \pm 13.8$ & - & - & $62.7 \%$ & - & USA [27] \\
\hline $90(53 \%)$ Male & $57 \pm 11$ & ICU & - & $38.29 \%$ & - & USA [28] \\
\hline 53(33\%) Male & $62 \pm 14.3$ & ICU & - & - & ARDS & USA [29] \\
\hline $\begin{array}{c}35(67 \%) \text { Male } \\
17(33 \%) \text { Female }\end{array}$ & $59 \cdot 7 \pm 13 \cdot 3$ & ICU & - & $\begin{array}{c}42 \% \\
22 \text { out of } 52\end{array}$ & ARDS & China [30] \\
\hline $\begin{array}{l}1304 \text { Male } \\
287 \text { Female }\end{array}$ & $\begin{array}{c}63 \text { (IQR } 56- \\
70)\end{array}$ & ICU & - & $\begin{array}{c}88 \% \\
1150 \text { out of } 1591\end{array}$ & $\begin{array}{l}\text { Hypoxia and } \\
\text { ARDS }\end{array}$ & $\begin{array}{c}\text { Italy, } \\
\text { Lombardy [5] }\end{array}$ \\
\hline $\begin{array}{l}\text { 49\% Male: PE } \\
\text { group } \\
\text { 45\% Male: non-PE } \\
\text { group }\end{array}$ & $\begin{array}{c}62 \pm 16 \mathrm{PE} \\
\text { group } \\
59 \pm 15 \text { non-PE } \\
\text { group }\end{array}$ & ICU & - & $\begin{array}{l}65 \% \text { in the } \mathrm{PE}^{2} \\
\text { group } \\
67 \% \text { in the non-PE } \\
\text { group }\end{array}$ & $\begin{array}{l}\text { Hypoxia } \\
\text { and PE }\end{array}$ & {$[58]$} \\
\hline
\end{tabular}




\begin{tabular}{|c|c|c|c|c|c|c|}
\hline No data available & $\begin{array}{c}\text { No data } \\
\text { available }\end{array}$ & ICU & $\begin{array}{c}44.5 \% \\
842 \text { out of } 1890\end{array}$ & $\begin{array}{c}16.4 \% \\
1890 \text { out of } 11493\end{array}$ & - & Spain [35] \\
\hline $\begin{array}{l}9 \text { Male } \\
7 \text { Female }\end{array}$ & $\begin{array}{c}58 \\
(\mathrm{IQR}, 47-68)\end{array}$ & ICU & - & $\begin{array}{l}56.25 \% \\
9 \text { out of } 16\end{array}$ & $\begin{array}{l}\text { Respiratory } \\
\text { failure }\end{array}$ & $\begin{array}{c}\text { Wuhan, China } \\
\text { [13] }\end{array}$ \\
\hline No data available & $\begin{array}{l}\text { No data } \\
\text { available }\end{array}$ & ICU & - & $\begin{array}{c}41.20 \% \\
82 \text { out of } 199\end{array}$ & $\begin{array}{l}\text { Acute } \\
\text { respiratory } \\
\text { failure }\end{array}$ & $\begin{array}{c}\text { Spain and } \\
\text { Andorra [33] }\end{array}$ \\
\hline $\begin{array}{l}28 \text { Male } \\
19 \text { Female }\end{array}$ & $\begin{array}{c}70 \text { years } \\
(\mathrm{IQR}, 63-77)\end{array}$ & ICU & - & $\begin{array}{c}48.9 \% \\
23 \text { out of } 47 \text { (early } \\
\text { intubation*) } \\
34 \% \\
16 \text { out of } 47 \text { (late } \\
\text { intubation**) }\end{array}$ & ARDS & $\begin{array}{c}\text { Daegu, South } \\
\text { Korea [34] }\end{array}$ \\
\hline $\begin{array}{l}88 \text { Male } \\
50 \text { Female }\end{array}$ & $\begin{array}{c}55 \text { cases } \leq 60 \\
\text { years } \\
83>60 \text { years }\end{array}$ & $\begin{array}{l}\text { ED, ICU and } \\
\text { other wards }\end{array}$ & $\begin{array}{c}56.5 \% \\
78 \text { out of } 138\end{array}$ & $\begin{array}{c}24.8 \% \\
138 \text { out of } 486\end{array}$ & $\begin{array}{l}\text { Decreased } \\
\text { Oxygen } \\
\text { saturation, } \\
\text { Shortness of } \\
\text { breath }\end{array}$ & $\begin{array}{c}\text { Chicago, USA } \\
{[35]}\end{array}$ \\
\hline $\begin{array}{l}92 \text { Male } \\
38 \text { Female }\end{array}$ & $\begin{array}{c}64.5 \text { years } \\
\text { (IQR, 51.7- } \\
73.6\end{array}$ & - & $\begin{array}{c}33.1 \% \\
43 \text { out of } 130\end{array}$ & $\begin{array}{c}33.1 \% \\
130 \text { out of } 393\end{array}$ & Dyspnea & $\begin{array}{l}\text { New York, } \\
\text { USA [9] }\end{array}$ \\
\hline $\begin{array}{l}25 \text { Male } \\
5 \text { Female }\end{array}$ & $\begin{array}{c}65.5 \text { years } \\
(\mathrm{IQR}, 57-71)\end{array}$ & - & $\begin{array}{c}20 \% \\
6 \text { out of } 30\end{array}$ & $\begin{array}{c}23.25 \% \\
30 \text { out of } 129\end{array}$ & Hypoxemia & $\begin{array}{l}\text { New Jersey, } \\
\text { USA [36] }\end{array}$ \\
\hline No data available & $\begin{array}{c}65 \text { years } \\
(\mathrm{IQR}, 53-77)\end{array}$ & $\begin{array}{l}\text { Various } \\
\text { wards }\end{array}$ & - & $\begin{array}{c}10.6 \% \\
467 \text { out of } 4389\end{array}$ & $\begin{array}{l}\text { Decreased } \\
\text { Oxygen } \\
\text { saturation, } \\
\text { Hypoxia }\end{array}$ & $\begin{array}{l}\text { New York, } \\
\text { USA [37] }\end{array}$ \\
\hline
\end{tabular}




\begin{tabular}{|c|c|c|c|c|c|c|}
\hline $\begin{array}{l}37 \text { Male } \\
45 \text { Female }\end{array}$ & $\begin{array}{c}\text { No data } \\
\text { available }\end{array}$ & - & - & $\begin{array}{c}33.75 \% \\
27 \text { out of } 82\end{array}$ & Hypoxia & $\begin{array}{c}\text { Chicago, USA } \\
\text { [38] }\end{array}$ \\
\hline $\begin{array}{l}112 \text { Male } \\
54 \text { Female }\end{array}$ & $58.1 \pm 14.1$ & ED & - & $\begin{array}{c}58 \% \text { (prone } \\
\text { positioning) } \\
33 \text { out of } 57 \\
49 \% \text { (No Prone) } \\
53 \text { out of } 109\end{array}$ & $\begin{array}{l}\text { Hypoxia, } \\
\text { tachypnea }\end{array}$ & $\begin{array}{l}\text { Sao Paulo, } \\
\text { Brazil [39] }\end{array}$ \\
\hline $\begin{array}{l}129 \text { Male } \\
93 \text { Female }\end{array}$ & $\begin{array}{c}69.5 \\
(\mathrm{IQR}, 62-78)\end{array}$ & $\begin{array}{l}\text { Various } \\
\text { wards }\end{array}$ & - & $\begin{array}{c}41 \% \text { (Intubation } \\
\text { First) } \\
91 \text { out of } 222 \\
20 \% \text { (NIV to } \\
\text { intubation) } \\
44 \text { out of } 222\end{array}$ & $\begin{array}{c}\text { ARDS, } \\
\text { Hypoxia, } \\
\text { Altered } \\
\text { Mental Status }\end{array}$ & $\begin{array}{c}\text { New York, } \\
\text { USA [40] }\end{array}$ \\
\hline
\end{tabular}

* Early intubation: intubation as soon as ARDS diagnosis

** Late intubation: not initially intubated, but subsequently required intubation during follow-up 
medRxiv preprint doi: https://doi.org/10.1101/2021.04.08.21254439; this version posted April 11, 2021. The copyright holder for this preprint

(which was not certified by peer review) is the author/funder, who has granted medRxiv a license to display the preprint in perpetuity.

It is made available under a CC-BY-NC-ND 4.0 International license.

Various statistics of intubation rates in COVID-19 patients are reported ranging from $5-88 \%$. This difference in statistics can be due to differences in sample size, study environment (wards), and intubation criteria [22,25]. Rapid sequence induction (RSI) or modified RSI was mostly used for intubation [41]. Propofol was used mostly in all patients often combined with other sedative agents like Rocuronium, Sufentanil, and Midazolam. Studies showed that factors affecting COVID-19 severity (such as underlying disease, age more than 50, smoking, body mass index, and comorbidity condition) could exacerbate a patient's condition and accelerate the necessity for endotracheal intubation [23,25]. The most important reasons that require endotracheal intubation are hypoxia, respiratory distress, loss of consciousness $[13,20,21]$. In a study by $\mathrm{Xu}$, et al. it was found that the intubation of critically ill patients with COVID-19 is mostly due to respiratory failure, but there is also a small number of patients who undergo intubation due to secondary acute heart failure or airway obstruction [42].

Some studies revealed that due to the limited capacity of intensive care units during the COVID-19 pandemic [43], tracheostomy seems to be a suitable solution for patients to get off the mechanical ventilation [44], reducing the respiratory effort in patients with limited pulmonary reserves, shortening the dead space and enabling the suctioning of accumulated mucous [32].

Despite the rarity of available studies regarding extubation in COVID-19 patients', some evidences revealed the extubation rate ranging $1.4 \%-44.5 \%[26,32]$.

As this study is a retrospective study, the number of studies included in this investigation is relatively small, and further large-scale prospective studies are needed to confirm our findings.

\section{Discussion and Conclusion}

SARS-CoV-2 is the coronavirus responsible for the COVID-19 pandemic of 2020. COVID-19 might induce severe respiratory distress. Acute respiratory distress in COVID-19 patients could require endotracheal intubation and mechanical ventilation. Proper intubation and management of patients with coronavirus are integral parts of critically ill patient's management. In confirmation, a study stated that of the patients who died only $\sim 25 \%$ received invasive mechanical ventilation (intubated) or ECMO [45]. It seems that lack of ventilator or delayed intubation might be one of the causes of deterioration disease in COVID-19 patients.

A study suggested that [46], less than a third of patients with coronavirus, might benefit from high-flow nasal cannula therapy, noninvasive ventilation, and awake prone position. Patients who have extubated might also benefit from this treatment strategy. The use of awake prone positioning as a supplement therapy to high-flow nasal oxygen therapy did not reduce the risk of intubation and mechanical 
medRxiv preprint doi: https://doi.org/10.1101/2021.04.08.21254439; this version posted April 11, 2021. The copyright holder for this preprint (which was not certified by peer review) is the author/funder, who has granted medRxiv a license to display the preprint in perpetuity.

It is made available under a CC-BY-NC-ND 4.0 International license.

ventilation [47]. However, it could cause delayed in intubation [33]. It seems that there are no significant differences in mortality rate between the early group and never intubated patients [34].

According to the necessity of intubation, specialists suggested the use of esophageal manometry (as a surrogate of pleural pressure) and consider intubation when pressure swings exceed $15 \mathrm{~cm} \mathrm{H} 2 \mathrm{O}$ identifying risk of self-inflicted lung injury [48]. Experience-based recommendations stated; once the patient's non-invasive ventilation failed, elective intubation should be preferred to minimize clinical risks such as contamination of medical staff [49]. Adequate application of personal protective equipment would reduce the risk of nosocomial infections for proceduralists [50].

Several factors might be associated with intubation in COVID-19 patients. Elderly patients, male gender and background diseases particularly hypertension and diabetes are more exposed to the risk of intubation $[1,35,50]$. Increased levels of ferritin, d-dimer, and lipase in common with hypoxia are correlated with intubation and ICU admission [36,38]. It was found that anticoagulation is associated with lower intubation [37]. The result of a study suggests that the ROX index is a noninvasive and outstanding predictor for the necessity of intubation in COVID-19 patients [51]. The ROX index is the ratio of oxygen saturation as measured by pulse oximetry/FiO2 to respiratory rate, it is assessed as a predictor of the need to intubate in patients who received high flow nasal cannula oxygen therapy [52].

Although appropriate positioning is an essential part of successful intubation, a study stated that awake prone positioning may not correlate with intubation rates [39]. Furthermore, there was no significant change in terms of $\mathrm{PaO} 2$ before Prone Positioning and $\mathrm{PaO} 2$ after resupination [53].

It seems that noninvasive ventilation (NIV) may have survival benefits so that patients who received NIV have lower mortality than patients who did not receive NIV and were intubated [40]. A study by Solaimanzadeh suggested that some calcium channel blocker agents like Nifedipine and Amlodipine may remarkably meliorate mortality and reduce the risk of intubation and the need for mechanical ventilation in Elder COVID-19 patients [54].

According to the studies the intubation rate reported 5 to $88 \%$. In the review study by da Silva CM et al, intubation need vary from 2, 3, 4, to $42 \%$ and $47 \%$ [55]. Besides, Cardona et al reported that the intubation rate was 28\% among hypoxic COVID-19 patients [56]. This discrepancy in statistics may be due to the variety of study population, study environment, or intubation criteria. However, there are a few pieces of evidence regarding extubation, therefore; more investigations are required to determine intubation outcomes and extubation. A study stated that obesity and age are the only risk factors of delayed or difficult extubation [35]. 
medRxiv preprint doi: https://doi.org/10.1101/2021.04.08.21254439; this version posted April 11, 2021. The copyright holder for this preprint (which was not certified by peer review) is the author/funder, who has granted medRxiv a license to display the preprint in perpetuity.

It is made available under a CC-BY-NC-ND 4.0 International license.

In terms of mortality subsequent of COVID-19 patients' intubation, it was reported vary from $15.2 \%$ [35], 23.1\% [21], 24.5\% [4], to 36.0\% [57]. Hernandez-Romieu et al [47] found no association between time to intubation and mortality of infected patients.

Due to the lack of definitive treatment for COVID-19, and the empirical treatments based on research, it seems that a comprehensive intubation algorithm in COVID-19 patients is extensively required.

The findings of this study are a review of intubation rates based on previous studies. These statistics are preliminary and more research is needed to examine the correlation and the factors affecting the intubation of patients.

\section{Recommendations}

According to studies and experience, we hereby offer recommendations that might improve the quality of care.

Utilize full personal protective equipment to prevent transmission.

It is better than the most experienced specialist intubates patients. (Perfectly first attempt)

Noninvasive ventilation may correct oxygenation and have survival benefits. It can be considered for patients who tolerate it.

Rapid sequence induction in combination with video laryngoscopy enabled swift intubation [30].

Necessary equipment should be available prior to intubation procedure (monitoring, intravenous access, resuscitator medications, ventilator, and suction) [61]

Consider calcium channel blocker agents (particularly Nifedipine and Amlodipine) for hypertensive patients [60]. (if applicable)

\section{Conflict of interest}

The authors have no conflict of interest to declare.

\section{Acknowledgement}

We hereby thanks all healthcare providers (hospital staff, nurses, doctors) around the world. We are grateful to the esteemed faculty members of Tehran University of medical sciences, the anesthesiology, and critical care department. \#thanks_heros 
medRxiv preprint doi: https://doi.org/10.1101/2021.04.08.21254439; this version posted April 11, 2021. The copyright holder for this preprint (which was not certified by peer review) is the author/funder, who has granted medRxiv a license to display the preprint in perpetuity.

It is made available under a CC-BY-NC-ND 4.0 International license .

\section{References}

1 - Mohammadi M, Varpaei HA, Amini M. Intubation prognosis in COVID-19 patients and associated factors: a cross-sectional study [Internet]. Research Square. 2020. Available from: http://dx.doi.org/10.21203/rs.3.rs-115894/v1

2 - Wang J, Hajizadeh N, Moore EE, McIntyre RC, Moore PK, Veress LA, Yaffe MB, Moore $\mathrm{HB}$,Barrett CD. Tissue plasminogen activator (tPA) treatment for COVID-19 associated acute respiratorydistress syndrome (ARDS): a case series. Journal of thrombosis and haemostasis. $2020 \mathrm{Apr}$ 8.

3 - Ferrando C, Suarez-Sipmann F, Mellado-Artigas R, Hernández M, Gea A, Arruti E, Aldecoa C, Martínez-Pallí G, Martínez-González MA, Slutsky AS, Villar J. Clinical features, ventilatory management, and outcome of ARDS caused by COVID-19 are similar to other causes of ARDS. Intensive care medicine. 2020 Jul 29:1-2.

4 - Richardson S, Hirsch JS, Narasimhan M, Crawford JM, McGinn T, Davidson KW, Barnaby DP, Becker LB, Chelico JD, Cohen SL, Cookingham J. Presenting characteristics, comorbidities, and outcomes among 5700 patients hospitalized with COVID-19 in the New York City area. Jama. 2020 Apr 22.

5 - Grasselli G, Zangrillo A, Zanella A, Antonelli M, Cabrini L, Castelli A, Cereda D, Coluccello A, Foti G, Fumagalli R, Iotti G. Baseline characteristics and outcomes of 1591 patients infected with SARS-CoV-2 admitted to ICUs of the Lombardy Region, Italy. Jama. 2020 Apr 28;323(16):1574-81.

6 - Huang C, Wang Y, Li X, Ren L, Zhao J, Hu Y, Zhang L, Fan G, Xu J, Gu X, Cheng Z. Clinical features of patients infected with 2019 novel coronavirus in Wuhan, China. The lancet. 2020 Feb 15;395(10223):497-506.

7 - Meng L, Qiu H, Wan L, Ai Y, Xue Z, Guo Q, Deshpande R, Zhang L, Meng J, Tong C, Liu H. Intubation and ventilation amid the COVID-19 outbreak: Wuhan's experience. Anesthesiology. 2020 Jun;132(6):1317-32.

8 - Yang X, Yu Y, Xu J, Shu H, Liu H, Wu Y, Zhang L, Yu Z, Fang M, Yu T, Wang Y. Clinical course and outcomes of critically ill patients with SARS-CoV-2 pneumonia in Wuhan, China: a single-centered, retrospective, observational study. The Lancet Respiratory Medicine. 2020 Feb 24.

9 - Goyal P, Choi JJ, Pinheiro LC, Schenck EJ, Chen R, Jabri A, Satlin MJ, Campion Jr TR, Nahid M, Ringel JB, Hoffman KL. Clinical characteristics of Covid-19 in New York city. New England Journal of Medicine. 2020 Apr 17.

10 - Wali A, Rizzo V, Bille A, Routledge T, Chambers AJ. Pneumomediastinum following intubation in COVID-19 patients: a case series. Anaesthesia. 2020 Aug;75(8):1076-81.

11 - Gulart AA, Silva IJ. Early prone position for COVID-19 patients with severe hypoxia: reduces the mortality but increases the intubation risk?. Intensive Care Medicine. 2020 Aug 20:1-2.

12 - Kangelaris KN, Ware LB, Wang CY, Janz DR, Hanjing Z, Matthay MA, Calfee CS. Timing of Intubation and Clinical outcomes in Adults with ARDS. Critical care medicine. 2016 Jan;44(1):120. 
medRxiv preprint doi: https://doi.org/10.1101/2021.04.08.21254439; this version posted April 11, 2021. The copyright holder for this preprint (which was not certified by peer review) is the author/funder, who has granted medRxiv a license to display the preprint in perpetuity.

It is made available under a CC-BY-NC-ND 4.0 International license .

13 - Lu X, Zhang M, Qian A, Tang L, Xu S. Lung ultrasound score in establishing the timing of intubation in COVID-19 interstitial pneumonia: A preliminary retrospective observational study. Plos one. 2020 Sep 3;15(9):e0238679.

14 - Brewster DJ, Chrimes NC, Do TB, Fraser K, Groombridge CJ, Higgs A, Humar MJ, Leeuwenburg TJ, McGloughlin S, Newman FG, Nickson CP. Consensus statement: Safe Airway Society principles of airway management and tracheal intubation specific to the COVID-19 adult patient group. Med J Aust. 2020 Mar 16;16.

15 - Tobin MJ, Laghi F, Jubran A. Why COVID-19 silent hypoxemia is baffling to physicians. American Journal of Respiratory and Critical Care Medicine. 2020 Aug 1;202(3):356-60.

16 - Ling L, Joynt GM, Lipman J, Constantin JM, Joannes-Boyau O. COVID-19: a critical care perspective informed by lessons learnt from other viral epidemics. Anaesthesia, Critical Care \& Pain Medicine. 2020 Apr;39(2):163.

17 - Tran K, Cimon K, Severn M, Pessoa-Silva CL, Conly J. Aerosol generating procedures and risk of transmission of acute respiratory infections to healthcare workers: a systematic review. PloS one. 2012 Apr 26;7(4):e35797.

18 - Fowler RA, Guest CB, Lapinsky SE, Sibbald WJ, Louie M, Tang P, Simor AE, Stewart TE. Transmission of severe acute respiratory syndrome during intubation and mechanical ventilation. American Journal of Respiratory and Critical Care Medicine. 2004 Jun 1;169(11):1198-202.

19 - Chen L, Liu HG, Liu W, Liu J, Liu K, Shang J, Deng Y, Wei S. Analysis of clinical features of 29 patients with 2019 novel coronavirus pneumonia. Zhonghua jie he he hu xi za zhi=Zhonghua jiehe he huxi zazhi= Chinese journal of tuberculosis and respiratory diseases. 2020 Feb 6;43:E005-.

20- Toussie D, Voutsinas N, Finkelstein M, Cedillo MA, Manna S, Maron SZ, Jacobi A, Chung M, Bernheim A, Eber C, Concepcion J. Clinical and chest radiography features determine patient outcomes in young and middle age adults with COVID-19. Radiology. 2020 May 14:201754.

21 - Ansarin K, Tolouian R, Ardalan M, Taghizadieh A, Varshochi M, Teimouri S, Vaezi T, Valizadeh H, Saleh P, Safiri S, Chapman KR. Effect of bromhexine on clinical outcomes and mortality in COVID-19 patients: A randomized clinical trial. BioImpacts: BI. 2020;10(4):209.

22 - Caputo ND, Strayer RJ, Levitan R. Early Self-Proning in Awake, Non-intubated Patients in the Emergency Department: A Single ED's Experience During the COVID-19 Pandemic. Academic Emergency Medicine. 2020 May;27(5):375-8.

23 - Miyashita H, Mikami T, Chopra N, Yamada T, Chernyavsky S, Rizk D, Cruz C. Do patients with cancer have a poorer prognosis of COVID-19? An experience in New York City. Annals of Oncology. 2020 Apr 21.

24 - Sinha P, Mostaghim A, Bielick CG, McLaughlin A, Hamer DH, Wetzler LM, Bhadelia N, Fagan MA, Linas BP, Assoumou SA, Ieong MH. Early administration of Interleukin-6 inhibitors for patients with severe Covid-19 disease is associated with decreased intubation, reduced mortality, and increased discharge. International Journal of Infectious Diseases. 2020 Oct 1;99:28-33. 
medRxiv preprint doi: https://doi.org/10.1101/2021.04.08.21254439; this version posted April 11, 2021. The copyright holder for this preprint (which was not certified by peer review) is the author/funder, who has granted medRxiv a license to display the preprint in perpetuity.

It is made available under a CC-BY-NC-ND 4.0 International license .

25 - Luo J, Rizvi H, Preeshagul IR, Egger JV, Hoyos D, Bandlamudi C, McCarthy CG, Falcon CJ, Schoenfeld AJ, Arbour KC, Chaft JE. COVID-19 in patients with lung cancer. Annals of Oncology. 2020 Oct 1;31(10):1386-96.

26 - Bartoletti M, Pascale R, Cricca M, Rinaldi M, Maccaro A, Bussini L, Fornaro G, Tonetti T, Pizzilli G, Francalanci E, Giuntoli L. Epidemiology of invasive pulmonary aspergillosis among COVID-19 intubated patients: a prospective study. Clinical Infectious Diseases. 2020 Jul 28.

27 - Rojas-Marte G, Khalid M, Mukhtar O, Hashmi AT, Waheed MA, Ehrlich S, Aslam A, Siddiqui S, Agarwal C, Malyshev Y, Henriquez-Felipe C. Outcomes in patients with severe COVID-19 disease treated with tocilizumab: a case-controlled study. QJM: An International Journal of Medicine. 2020 Aug 1;113(8):546-50.

28 - Pereira MR, Mohan S, Cohen DJ, Husain SA, Dube GK, Ratner LE, Arcasoy S, Aversa MM, Benvenuto LJ, Dadhania DM, Kapur S. COVID-19 in solid organ transplant recipients: Initial report from the US epicenter. American Journal of Transplantation. 2020 Apr 24.

29 - Chao TN, Harbison SP, Braslow BM, Hutchinson CT, Rajasekaran K, Go BC, Paul EA, Lambe LD, Kearney JJ, Chalian AA, Cereda MF. Outcomes after Tracheostomy in COVID-19 Patients. Annals of Surgery. 2020 Sep;272(3):e181

30 - Sommer P, Lukovic E, Fagley E, Long DR, Sobol JB, Heller K, Moitra VK, Pauldine R, O'Connor MF, Shahul S, Nunnally ME. Initial clinical impressions of the critical care of COVID-19 patients in Seattle, New York City, and Chicago. Anesthesia and Analgesia. 2020 Apr 20.

31 - Poyiadji N, Cormier P, Patel PY, Hadied MO, Bhargava P, Khanna K, Nadig J, Keimig T, Spizarny D, Reeser N, Klochko C. Acute pulmonary embolism and COVID-19. Radiology. 2020 May 14:201955.

32 - Martin-Villares C, Molina-Ramirez CP, Bartolome-Benito M, Bernal-Sprekelsen M. Outcome of 1890 tracheostomies for critical COVID-19 patients: a national cohort study in Spain. European Archives of Oto-Rhino-Laryngology. 2020 Aug 4:1-8.

33 - Ferrando C, Mellado-Artigas R, Gea A, Arruti E, Aldecoa C, Adalia R, Ramasco F, Monedero P, Maseda E, Tamayo G, Hernández-Sanz ML. Awake prone positioning does not reduce the risk of intubation in COVID-19 treated with high-flow nasal oxygen therapy: a multicenter, adjusted cohort study. Critical Care. 2020 Dec;24(1):1-1.

34 - Lee YH, Choi KJ, Choi SH, Lee SY, Kim KC, Kim EJ, Lee J. Clinical Significance of Timing of Intubation in Critically Ill Patients with COVID-19: A Multi-Center Retrospective Study. Journal of clinical medicine. 2020 Sep;9(9):2847.

35 - Hur K, Price CP, Gray EL, Gulati RK, Maksimoski M, Racette SD, Schneider AL, Khanwalkar AR. Factors Associated With Intubation and Prolonged Intubation in Hospitalized Patients With COVID-19. Otolaryngology--Head and Neck Surgery. 2020 May 19.

36 - Mughal MS, Kaur IP, Jaffery AR, Dalmacion DL, Wang C, Koyoda S, Kramer VE, Patton CD, Weiner S, Eng MH, Granet KM. COVID-19 patients in a tertiary US hospital: Assessment of clinical course and predictors of the disease severity. Respiratory medicine. 2020 Oct 1;172:106130. 
medRxiv preprint doi: https://doi.org/10.1101/2021.04.08.21254439; this version posted April 11, 2021. The copyright holder for this preprint (which was not certified by peer review) is the author/funder, who has granted medRxiv a license to display the preprint in perpetuity.

It is made available under a CC-BY-NC-ND 4.0 International license .

37 - Nadkarni GN, Lala A, Bagiella E, Chang HL, Moreno PR, Pujadas E, Arvind V, Bose S, Charney AW, Chen MD, Cordon-Cardo C. Anticoagulation, bleeding, mortality, and pathology in hospitalized patients with COVID-19. Journal of the American College of Cardiology. 2020 Oct 20;76(16):1815-26.

38 - Barlass U, Wiliams B, Dhana K, Adnan D, Khan SR, Mahdavinia M, Bishehsari F. Marked elevation of lipase in covid-19 disease: a cohort study. Clinical and Translational Gastroenterology. $2020 \mathrm{Jul} ; 11 .(\vee)$

39 - Padrão EM, Valente FS, Besen BA, Rahhal H, Mesquita PS, de Alencar JC, da Costa MG, Wanderley AP, Emerenciano DL, Bortoleto FM, Fortes JC. Awake prone positioning in COVID-19 hypoxemic respiratory failure: exploratory findings in a single-center retrospective cohort study. Academic Emergency Medicine. 2020 Dec;27(12):1249-59.

40 - Daniel P, Mecklenburg M, Massiah C, Joseph MA, Wilson C, Parmar P, Rosengarten S, Maini R, Kim J, Oomen A, Zehtabchi S. Non-invasive positive pressure ventilation versus endotracheal intubation in treatment of COVID-19 patients requiring ventilatory support. The American journal of emergency medicine. 2021 May 1;43:103-8.

41 - Yao W, Wang T, Jiang B, Gao F, Wang L, Zheng H, Xiao W, Xu L, Yao S, Mei W, Chen X. Emergency tracheal intubation in 202 patients with COVID-19 in Wuhan, China: lessons learnt and international expert recommendations. British Journal of Anaesthesia. 2020 Apr 10.

42 - Xu Z, Shi L, Wang Y, Zhang J, Huang L, Zhang C, Liu S, Zhao P, Liu H, Zhu L, Tai Y. Pathological findings of COVID-19 associated with acute respiratory distress syndrome. The Lancet respiratory medicine. 2020 Apr 1;8(4):420-2.

43 - Antommaria AH, Gibb TS, McGuire AL, Wolpe PR, Wynia MK, Applewhite MK, Caplan A, Diekema DS, Hester DM, Lehmann LS, McLeod-Sordjan R. Ventilator triage policies during the COVID-19 pandemic at US hospitals associated with members of the association of bioethics program directors. Annals of Internal Medicine. 2020.

44 - Hamilton NJ. COVIDTrach; the outcomes of mechanically ventilated COVID-19 patients undergoing tracheostomy in the UK: Interim Report 22nd May 2020. medRxiv. 2020 Jan 1

45 - Xie J, Tong Z, Guan X, Du B, Qiu H, Slutsky AS. Critical care crisis and some recommendations during the COVID-19 epidemic in China. Intensive care medicine. 2020 Mar 2:1-4.

46 - Raoof S, Nava S, Carpati C, Hill NS. How I Do It: High Flow, Non-invasive ventilation and Awake (non-intubation) Proning in Covid-19 Patients with Respiratory Failure. Chest. 2020 Jul 15.

47 - Hernandez-Romieu AC, Adelman MW, Hockstein MA, Robichaux CJ, Edwards JA, Fazio JC, Blum JM, Jabaley CS, Caridi-Scheible M, Martin GS, Murphy DJ. Timing of intubation and mortality among critically ill coronavirus disease 2019 patients: a single-center cohort study. Critical care medicine. 2020 Aug 25.

48 - Apigo M, Schechtman J, Dhliwayo N, Al Tameemi M, Gazmuri RJ. Development of a work of breathing scale and monitoring need of intubation in COVID-19 pneumonia. Critical Care. 2020 Dec;24(1):1-3. 
medRxiv preprint doi: https://doi.org/10.1101/2021.04.08.21254439; this version posted April 11, 2021. The copyright holder for this preprint (which was not certified by peer review) is the author/funder, who has granted medRxiv a license to display the preprint in perpetuity.

It is made available under a CC-BY-NC-ND 4.0 International license .

49- Sorbello M, Morello G, Pintaudi S, Cataldo R. COVID-19: Intubation Kit, Intubation Team, or Intubation Spots?. Anesthesia \& Analgesia. 2020 Aug 1;131(2):e128-30.

50 - Zheng H, Li S, Sun R, Yang H, Chi X, Chen M, Xu L, Deng Q, Li X, Yu J, Wan L. Clinical experience with emergency endotracheal intubation in COVID-19 patients in the intensive care units: a single-centered, retrospective, descriptive study. American Journal of Translational Research. 2020;12(10):6655.

51 - Patel M, Chowdhury J, Mills N, Marron R, Gangemi A, Dorey-Stein Z, Yousef I, Tragesser L, Giurintano J, Gupta R, Rali P. ROX Index Predicts Intubation in Patients with COVID-19 Pneumonia and Moderate to Severe Hypoxemic Respiratory Failure Receiving High Flow Nasal Therapy. medRxiv. 2020 Jan 1.

52 - Roca O, Caralt B, Messika J, Samper M, Sztrymf B, Hernández G, García-de-Acilu M, Frat JP, Masclans JR, Ricard JD. An index combining respiratory rate and oxygenation to predict outcome of nasal high-flow therapy. American journal of respiratory and critical care medicine. 2019 Jun 1;199(11):1368-76.

53 - Elharrar X, Trigui Y, Dols A, et al. Use of Prone Positioning in Nonintubated Patients With COVID-19 and Hypoxemic Acute Respiratory Failure. JAMA. 2020;323(22):2336-2338.

doi:10.1001/jama.2020.8255

54 - Solaimanzadeh I. Nifedipine and amlodipine are associated with improved mortality and decreased risk for intubation and mechanical ventilation in elderly patients hospitalized for COVID19. Cureus. 2020 May;12(5).

55 - da Silva CM, do Nascimento Andrade A, Nepomuceno B, Xavier DS, Lima E, Gonzalez I, Esquivel MS, Novais MC, Magalhães P, da Silva Almeida R, Gomes VA. Evidence-based Physiotherapy and Functionality in Adult and Pediatric patients with COVID-19. Journal of Human Growth and Development. 2020 Apr 14;30(1):148-55.

56 - Cardona S, Downing J, Alfalasi R, Bzhilyanskaya V, Milzman D, Rehan M, Schwartz B, Yardi I, Yazdanpanah F, Tran QK. Intubation rate of patients with hypoxia due to COVID-19 treated with awake proning: A meta-analysis. The American Journal of Emergency Medicine. 2021 May 1;43:8896.

57 - Orser BA. Recommendations for endotracheal intubation of COVID-19 patients. Anesth Analg. 2020 May 1;130(5):1109-10

58 - Poyiadji N, Cormier P, Patel PY, Hadied MO, Bhargava P, Khanna K, Nadig J, Keimig T, Spizarny D, Reeser N, Klochko C. Acute pulmonary embolism and COVID-19. Radiology. 2020 May 14:201955. 